\title{
Editorial
}

\section{O esforço de publicar duas revistas por número}

Certamente iniciamos o ano de 2005 no melhor momento já vivenciado pela Revista de Psiquiatria do Rio Grande do Sul. Nesse 26을 ano de nossa Revista, somam-se à história de 25 anos de publicações ininterruptas a distribuição nacional a mais de 5.000 colegas psiquiatras e instituições, a presença em diversos indexadores importantes, a qualificação nível A pela CAPES e o reconhecimento, por parte da comunidade psiquiátrica acadêmica e não-acadêmica de nosso país, da qualidade de nossa Revista. Esse reconhecimento tem sido observado por nós, do Conselho Editorial, através de dois aspectos: o primeiro consiste no envio constante de artigos ao longo de todo o ano; o segundo aspecto desse reconhecimento se dá pela origem desses artigos: atualmente, cerca de dois terços dos artigos em nosso banco são de origem não-gaúcha, o que bem demonstra que hoje nossa Revista efetivamente tornou-se um veículo de divulgação do pensamento psiquiátrico brasileiro.

Mas, para além desses aspectos históricos e contemporâneos de nosso crescimento, parece-nos fundamental a solidificação de nossa linha editorial. A estruturação de uma linha editorial não se estabelece do dia para a noite. É resultado dos esforços de vários
Conselhos Editoriais anteriores, somados às características muito peculiares do pensamento psiquiátrico do nosso meio. Desde sempre, a psiquiatria do Rio Grande do Sul aprendeu o significado da palavra "convivência". Aqui convivem harmonicamente psiquiatras de tradição analítica, outros de orientação mais clínica, pesquisadores de áreas básicas afins, terapeutas cognitivistas e de outras correntes psiquiátricas e psicoterápicas. Desta forma, a linha editorial da Revista de Psiquiatria do Rio Grande do Sul se destaca e se difere de outras publicações co-irmãs exatamente porque tem este aspecto peculiar: a publicação de artigos que refletem $o$ que se pesquisa em nossos centros de excelência ao lado de artigos que refletem tão-somente a - bastante importante prática clínica psiquiátrica e psicoterápica cotidiana realizada por nossos colegas brasileiros. Entendemos que este é o nosso diferencial, e, assim como cada publicação em nossa área tem se firmado por uma determinada característica, esta tem sido a nossa - talvez justamente esta característica seja a responsável pelo estágio que agora conquistamos.

Ao mesmo tempo em que nossas atenções estão voltadas para a circulação dos artigos em nosso país, também estamos atentos para que 
esses artigos sejam reconhecidos e lidos fora do Brasil. Para isso, temos editado, desde o ano passado, duas revistas por número: uma impressa, totalmente em português, e outra em versão eletrônica, totalmente em língua inglesa, disponível no site internacional do Scielo. Essa postura nos traz muito mais trabalho e um custo infinitamente maior. Entretanto, entendemos que, ao editar duas revistas por número, estamos cumprindo nossa missão editorial voltada para o público interno, em sua línguamãe, e em inglês, para que o público externo conheça e valorize o que aqui se produz.

Duas revistas por número é o nosso desafio atual, cumprido com denodo e com o prazer de estarmos contribuindo para o crescimento científico da psiquiatria brasileira.

Flávio Shansis e Jacó Zaslavsky Editores 